\title{
p53 protein accumulation in oesophageal squamous cell carcinomas and precancerous lesions
}

\author{
A Volant, J-B Nousbaum, M-A Giroux, I Roué-Quintin, J-P Metges, C Férec, \\ H Gouérou, M Robaszkiewicz
}

\begin{abstract}
Aims-To investigate the immunohistochemical expression of $\mathrm{p} 53$ protein in oesophageal squamous cell carcinomas and in dysplastic areas of the oesophageal mucosa surrounding the tumours.

Methods-Biopsy samples were obtained from 20 patients with an oesophageal squamous cell carcinoma. Blocks of the tumours and of the surrounding mucosa were immunostained with the monoclonal antibody DO-7.

Results-Fourteen of the 20 carcinomas were positive for $\mathrm{p} 53(\mathbf{7 0} \%)$. The frequency of p53 overexpression increased with the differentiation of the tumour. Nine out of 13 dysplastic specimens were positive for p53 (69\%): eight cases with severe dysplasia and one case with moderate dysplasia. No p53 immunostaining was detected in normal oesophageal epithelium. All p53 positive dysplastic specimens were taken from the mucosa adjacent to tumours that were also immunostained. In moderate dysplastic mucosa the p53 positive cells were located in the proliferative basal zone, whereas in severe dysplasia the immunostained cells increased in number and spread to upper cell layers of the epithelium.

Conclusion-This study supports the hypothesis that TP53 gene is frequently involved in the development of oesophageal squamous cell carcinoma and that $p 53$ protein accumulation is an early event in human oesophageal carcinogenesis.

(f Clin Pathol 1995;48:531-534)
\end{abstract}

Keywords: Oesophageal neoplasma, squamous cell carcinoma, dysplasia, p53 protein.

The incidence of oesophageal carcinoma varies widely in different parts of the world. Squamous cell carcinoma of the oesophagus is common in north west France, where alcohol

Accepted for publication

3 November 1994 consumption and tobacco use have been implicated as important risk factors. ${ }^{12}$ Multiple stages of oesophageal carcinogenesis have been defined histologically and it has been established that oesophageal carcinoma usually evolves through a series of progressively severe dysplastic changes. ${ }^{3-5}$ The molecular pathogenesis of oesophageal carcinogenesis is just beginning to be understood. The importance of tumour suppressor gene loci in oesophageal cancer has been emphasised recently. ${ }^{6}$ TP53 is a tumour suppressor gene located on the short arm of chromosome 17, which encodes a nuclear phosphoprotein (p53) that appears to play an important role in the control of the cell cycle, DNA repair and synthesis, cell differentiation, and apoptosis. ${ }^{78}$ Mutant forms of TP53 gene that can act as dominant oncogenes are usually associated with a change in the conformation of p53 protein. Mutant p53 proteins have a much longer half life than the wild type protein, leading to its accumulation in the cell, which can be detected using specific antibodies. ${ }^{910}$ Several reports indicate that TP53 gene alterations are common in oesophageal squamous cell carcinoma ${ }^{11-14}$; in a recent study we found that mutations in the TP53 were present in $82 \%$ of cases. ${ }^{15}$ There is little information about TP53 alterations in premalignant squamous lesions of the oesophagus and the time at which these alterations occur during the development of oesophageal squamous cell carcinoma. The aim of this study was to analyse the expression of $\mathrm{p} 53$ protein by immunohistochemistry in biopsy specimens taken from oesophageal carcinomas, and from the mucosa surrounding the cancer.

\section{Methods}

The biopsy samples were obtained from 20 consecutive patients with an oesophageal squamous cell carcinoma. Biopsies were taken from both the tumour and the adjacent oesophageal mucosa during an endoscopy or on resected specimens. No patient had chemotherapy or radiation therapy before the biopsies were taken. Paraffin embedded tissue blocks of formalin fixed biopsy specimens were then processed for conventional histological assessment and immunohistochemical analysis using the avidin-biotin method. Five micrometre thick sections were cut and mounted on poly- $L$-lysine coated slides, and one of each was stained with haematoxylin and eosin $(\mathrm{H}$ and $\mathrm{E}) . \mathrm{H}$ and $\mathrm{E}$ stained sections were reviewed by a single pathologist (AV). Specimens were carcinomas (SCC)

\begin{tabular}{lccc}
\hline & & \multicolumn{2}{l}{$p 53$ positive } \\
\cline { 3 - 4 } Diagnosis & Total number & $n$ & $\%$ \\
\hline Well differentiated SCC & 12 & 10 & $83 \cdot 3$ \\
Moderately differentiated SCC & 6 & 4 & $66 \cdot 6$ \\
Poorly differentiated SCC & 2 & 0 & \\
Severe dysplasia & 12 & 8 & $66 \cdot 6$ \\
Moderate dysplasia & 1 & 1 & \\
\hline
\end{tabular}


classified according to type and differentiation of the carcinoma based on the World Health Organisation histological classification of squamous cell carcinoma of the oesophagus. ${ }^{16}$

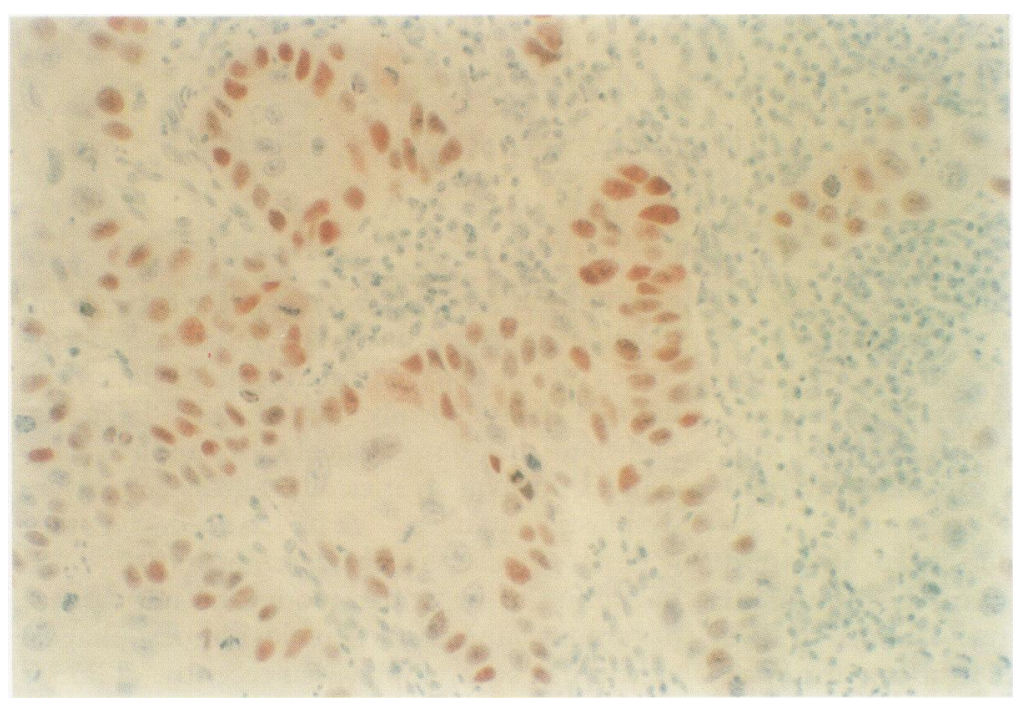

Figure 1 Well differentiated squamous cell carcinoma of the oesophagus.

Immunohistochemical staining with DO-7 monoclonal antibody. Tumour with high expression of $p 53$ gene product; diffuse and intense nuclear staining of a majority of nuclei is present.

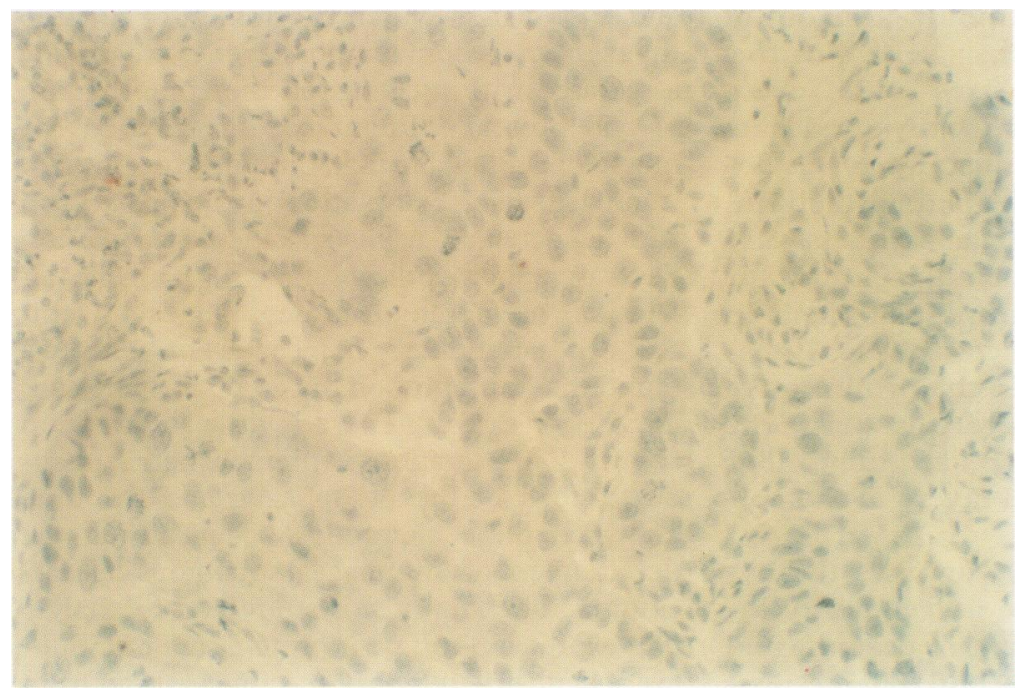

Figure 2 Immunohistochemical staining with DO-7 monoclonal antibody. Well differentiated squamous cell carcinoma of the oesophagus without p53 protein expression.
Dysplastic abnormalities in oesophageal mucosal lesions of squamous cell carcinoma were graded as mild, moderate, and severe dysplasia.

Sections from all cases were immunostained for p53. All incubations were performed at room temperature and all washes were made using phosphate buffered saline (PBS). Sections $5 \mu \mathrm{m}$ thick were taken onto silanised slides and dried at $37^{\circ} \mathrm{C}$ overnight. Deparaffinised slides were immersed in $600 \mathrm{ml}$ of $0.01 \mathrm{M}$ citrate buffer, $\mathrm{pH} 6$, for microwave antigen retrieval and irradiated in a domestic microwave oven $(750 \mathrm{~W})$ at full power for 20 minutes. All sections were immunostained with the streptavidin-biotin method. The monoclonal antibody used was DO-7 (Dako SA). DO-7 recognises an epitope in the $\mathrm{N}$ terminus of the human p53 protein between amino acids 35 and 45 . This epitope is expressed by wild type as well as mutant types of p53 protein. The antibody was diluted 1:50 and then applied for one hour at room temperature. Positive staining was visualised with 3-amino 9-ethyl carbazole substrate solution $(2 \mathrm{mg} / \mathrm{ml}$ in $0.1 \mathrm{M}$ acetate buffer, $\mathrm{pH} 5 \cdot 2$, with $0.04 \% \mathrm{H}_{2} \mathrm{O}_{2}$ ). Counterstaining of the nuclei was done with Mayer's haematoxylin. Sections were mounted in DPX. Positive control slides included in each run consisted of a colonic carcinoma overexpressing p53 protein. The slides stained with the DO-7 monoclonal antibody were then analysed by the same pathologist. Cases were called positive for $\mathrm{p} 53$ if there was any nuclear staining, with no preset percentage or intensity threshold. The results of p53 staining and histological grading were then reviewed jointly and correlated.

\section{Results}

The histological findings of these 20 cases of oesophageal squamous cell carcinoma are listed in table 1 . In 13 cases dysplastic abnormalities were found in the mucosa surrounding the tumour. These lesions were graded as severe dysplasia in 12 cases and moderate dysplasia in one case. The results of p53 staining are also listed in table 1 . Fourteen of the 20 squamous cell carcinomas were positive for p53 $(70 \%)$. This table shows that the percentage

Table 2 Characteristics of oesophageal cancers and surrounding mucosa tested for p53 mutations

\begin{tabular}{|c|c|c|c|c|c|c|c|c|}
\hline Patient & Sex & Age & $\begin{array}{l}\text { Alcohol consumption } \\
>80 \text { g/day }\end{array}$ & Smoking & $\begin{array}{l}\text { Tumour } \\
\text { differentiation }\end{array}$ & $\begin{array}{l}\text { p53 } \\
\text { overexpression }\end{array}$ & Dysplasia & $\begin{array}{l}p 53 \\
\text { overexpression }\end{array}$ \\
\hline 1 & $M$ & 51 & + & + & $\mathrm{w}$ & + & + & + \\
\hline 2 & $\mathrm{M}$ & 69 & - & + & $\mathrm{W}$ & + & + & + \\
\hline 3 & $M$ & 59 & + & + & W & + & + & + \\
\hline 4 & $M$ & 72 & + & + & W & + & + & + \\
\hline 5 & $M$ & 69 & + & + & W & + & + & + \\
\hline 6 & $\mathbf{M}$ & 49 & + & + & W & + & + & + \\
\hline 7 & $\mathrm{M}$ & 55 & + & + & W & + & + & + \\
\hline 8 & $M$ & 46 & - & + & W & + & - & \\
\hline 9 & $\mathrm{~F}$ & 88 & - & - & W & + & - & \\
\hline 10 & $\mathbf{M}$ & 50 & + & + & W & + & - & \\
\hline 11 & $\mathbf{M}$ & 52 & + & + & W & - & + & - \\
\hline 12 & $M$ & 66 & + & + & W & - & + & - \\
\hline 13 & $\mathrm{M}$ & 57 & - & + & $\mathbf{M}$ & + & + & + \\
\hline 14 & $\mathbf{M}$ & 69 & - & + & $\mathbf{M}$ & + & + & + \\
\hline 15 & $\mathrm{M}$ & 40 & + & + & $\mathbf{M}$ & + & - & \\
\hline 16 & $\mathbf{M}$ & 51 & + & + & $M$ & + & - & \\
\hline 17 & $\mathbf{M}$ & 67 & + & + & $\mathbf{M}$ & - & + & - \\
\hline 18 & $\mathrm{M}$ & 80 & + & + & $\mathbf{M}$ & - & + & - \\
\hline 19 & $\mathrm{M}$ & 82 & - & - & $\mathrm{P}$ & - & - & \\
\hline 20 & $\mathbf{M}$ & 68 & + & + & $\mathbf{P}$ & - & - & \\
\hline
\end{tabular}




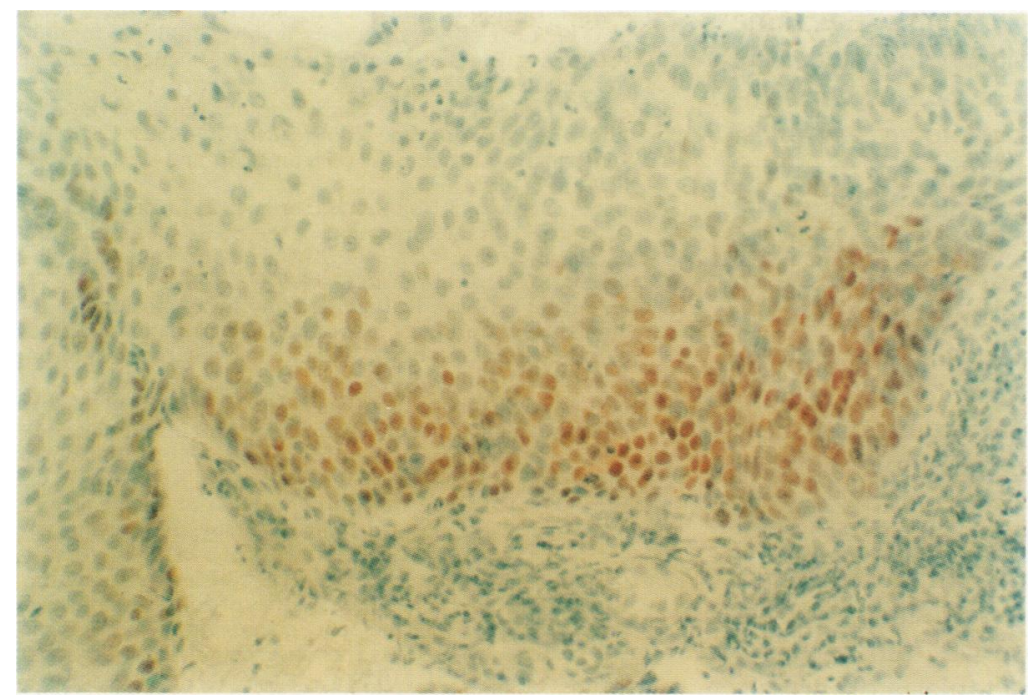

Figure 3 p53 immunohistochemical analysis of moderately dysplastic mucosa. p53 positive cells are located in the proliferative basal zone of the squamous epithelium. This biopsy specimen was taken from oesophageal mucosa surrounding a p53 positive squamous cell carcinoma.

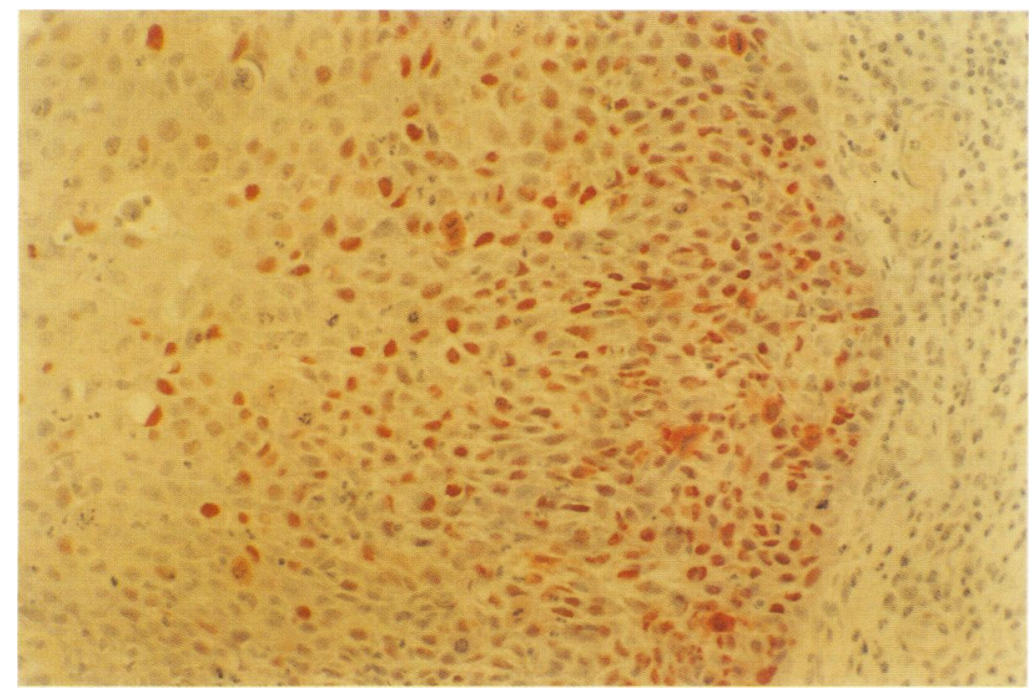

Figure 4 p53 positive immunostaining of squamous epithelium with severe dysplasia. The lower and upper epithelial layers contain immunostained cells with enlarged, irregularly shaped, dysplastic nuclei. cell layers of the epithelium (fig 4). No p53 immunostaining was detected in normal oesophageal epithelium.

\section{Discussion}

This study confirms the high prevalence of p53 alterations in oesophageal squamous cell carcinoma. However, the frequency of p53 overexpression was lower than the $84 \%$ prevalence of p53 mutations found in a previous study in which we used denaturing gradient gel electrophoresis and DNA sequencing. ${ }^{15}$ It is established that the relatively low levels of wild type p53 protein in normal cells are generally undetectable by immunohistochemical techniques. On the other hand, mutant $\mathrm{p} 53$ proteins accumulate in the cell because of their prolonged half life, and there is a correlation between the overexpression of $\mathrm{p} 53$ protein and the presence of a missense mutation in the TP53 gene. ${ }^{17}$ Nevertheless, the concordance between a TP53 gene mutation and p53 overexpression is not perfect. The levels of p53 are generally undetectable by immunohistochemistry in cells with frameshift or nonsense mutations in the coding sequences of the gene, because the resultant protein is absent, truncated, or unstable. ${ }^{7}$ On the other hand, stabilisation of wild type $\mathrm{p} 53$ protein by cellular or viral proteins can lead to p53 immunodetection. Thus our results showing p53 overexpression in $70 \%$ of oesophageal squamous cell carcinomas are consistent with those of our previous study, since $21 \%$ of the TP53 gene alterations that we identified in oesophageal carcinomas were frameshift mutations. ${ }^{15}$ This also suggests that non-mutational stabilisation of p53 protein is an uncommon mechanism for p53 immunopositivity in oesophageal squamous cell carcinoma.

We detected p53 overexpression in dysplastic oesophageal mucosa in nine of 13 patients who had such lesions (69\%). All p53 positive dysplastic biopsy specimens were taken from oesophageal mucosa surrounding carcinomas in which p53 expression was detected. Neither dysplastic mucosa next to $\mathrm{p} 53$ negative tumours nor oesophageal mucosa without dysplasia showed p53 immunostaining. These data suggest that TP53 alterations may precede invasion in oesophageal carcinogenesis. Similar results have been observed by Bennett et $a l^{18}$ who detected high levels of p53 protein expression by immunohistochemistry in both preinvasive dysplastic lesions and invasive oesophageal squamous cell carcinoma in six of nine cases. In that study, missense mutations in the TP53 gene were detected in only two tumours. In one case, different mutations were found in the invasive carcinoma and in a preinvasive lesion suggesting that oesophageal carcinomas may arise from independent clones of cells. In a study performed on samples from an area with high oesophageal cancer incidence in China, Wang et al ${ }^{19}$ also observed p53 immunostaining in cancerous and precancerous lesions. Interestingly, the p53 immunostained cells increased in number from basal cell hyperplasia to dysplasia and carcinoma in situ, the mucosa adjacent to tumours that were p53 positive. In moderately dysplastic mucosa the p53 positive cells were located in the proliferative basal zone (fig 3 ), whereas in severe dysplasia the immunostained cells increased in number and were also present in the upper 
and their distribution had roughly the same pattern as that of the proliferating cells. We observed a similar pattern of p53 protein immunostaining in dysplastic biopsy samples. Positive cells were distributed in the proliferative basal cell zone in moderate dysplasia, increasing in number and spreading to upper cell layers of the epithelium in samples with severe dysplasia. These findings suggest that basal cells may be the earliest site for oesophageal carcinogenesis.

Recent studies indicate that alterations of the TP53 gene and p53 overexpression can occur in precancerous lesions of the colon, skin, and breast, and in Barrett's oesophagus. ${ }^{20-24}$ Barrett's oesophagus is a condition that predisposes to the development of oesophageal adenocarcinoma, which develops by a multistep process in which specialised metaplasia progresses to cancer through progressively dysplastic changes. $^{25}$ In Barrett's oesophagus, the frequency of p53 overexpression also increases with the severity of the dysplasia and probably precedes the phenotypic changes characteristic of dysplasia. ${ }^{2627}$ This study confirms that TP53 plays an important role in the development of oesophageal squamous cell carcinoma and that p53 protein accumulation is an early event in human oesophageal carcinogenesis. Additional work is needed to determine whether p53 protein accumulation in preinvasive lesions of oesophageal squamous cell carcinoma is associated with TP53 gene mutations or alternative mechanisms such as p53 protein stabilisation through binding with cellular proteins. Accumulation of $\mathrm{p} 53$ protein, as detected by immunohistochemistry, may be an objective early biomarker for identifying high risk subjects for oesophageal squamous cell carcinoma.

1 Calament G, Cauvin JM, Robaszkiewicz M, Nousbaum JB, Lepage, Robert FX, et al. Traitement et survie du cancer epidermoide de l'oesophage dans le departement du Finistère entre 1984

2 Tuyns AJ, Pequignot G, Jensen OM. Le cancer de l'oesophage en Ille et Vilaine en fonction des niveaux de consommation d'alcool et de tabac. Des risques qui se multiplient. Bull Cancer 1977;64:45-60.

3 Yang CS. Research on esophageal cancer in China: a review. Cancer Res 1980;40:2633-44.

4 Qiu SL, Yang GR. Precursor lesions of esophageal cancer in high-risk populations in Henan province, China. Cancer 1988;62:551-7.

5 Correa P. Precursors of gastric and esophageal cancer. Cancer 1982;50:2554-65.
6 Huang Y, Boyton RF, Blount PL, Silverstein RJ, Yin J, Tong $\mathrm{Y}$, et al. Loss of heterozygosity involves multiple tumour , et al. Loss of heterozygosity involves multiple tumour Res 1992;52:6525-30.

7 Harris CC, Hollstein M. Clinical implications of the p53 tumor-suppressor gene. N Engl f Med 1993;329:1318-27.

8 Vogelstein B, Kinzler KW. p53 function and dysfunction. Cell 1992;70:523-6.

9 Bartek J, Bartkova J, Vojtësek B, Staskova Z, Lukas J, Rejthar $\mathrm{A}$, et al. Aberrant expression of the p 53 oncoprotein is a common feature of a wide spectrum of human malignancies. Oncogene 1991;6:1699-703.

10 Gannon JV, Greaves R, Iggo R, Lane DP. Activating mutations in $\mathrm{p} 53$ produce a common conformational effect: a monoclonal antibody specific for the mutant form. a monoclonal antibody sp

11 Hollstein MC, Metcalf RA, Welsh JA, Montesano R, Harris CC. Frequent mutation of the p53 gene in human esophageal cancer. Proc Natl Acad Sci USA 1990;87:9958-61.

12 Meltzer SJ, Yin J, Huang Y, McDaniel TK, Newkirk C Iseri $\mathrm{O}$, et al. Reduction to homozygosity involving p 53 in esophageal cancers demonstrated by the polymerase chain reaction. Proc Natl Acad Sci USA 1991;88:4976-80.

13 Hollstein MC, Peri L, Mandard AM, Welsh JA, Montesano $\mathrm{R}$, Metcalf RA, et al. Genetic analysis of human esophageal p 53 base substitutions and absence of ras mutations. p53 base substitutions and

14 Wagata T, Shibagaki I, Imamura M, Shimada Y, Toguchida $\mathrm{J}$, Yandell DW, et al. Loss of $17 \mathrm{p}$, mutation of the $\mathrm{p} 53$ gene and overexpression of $\mathrm{p} 53$ protein in esophageal squamous cell carcinomas. Cancer Res 1993;53:846-50.

15 Audrezet MP, Robaszkiewicz M, Mercier B, Nousbaum JB, Bail JP, Hardy E, et al. TP53 gene mutation profile in esophageal squamous cell carcinomas. Cancer Res 1993; 53:5745-49.

16 Watanabe H, Jass JR, Sobin LH, eds, in collaboration with pathologists in 8 countries. Histological typing of esophageal and gastric tumours, 2nd ed. Berlin: Springer Verlag, 1990: and gastric $11-14$.

17 Hollstein M, Sidransky D, Vogelstein B, Harris CC. p53 mutations in human cancers. Science 1991;253:49-53.

18 Bennett WP, Hollstein MC, Metclaff RA, Welsh JA, He A Zhu $S$, et al. p 53 mutation and protein accumulation during multistage human esophageal carcinogenesis. Cancer Res 1992;52:6092-7.

19 Wang LD, Hong JY, Qiu SL, Gao H, Yang CS. Accumulation of $\mathrm{p} 53$ protein in human esophageal precancerous lesions: a possible early biomarker for carcinogenesis. Cancer Res 1993;53:1783-7.

20 Kaklamanis L, Gatter KC, Mortensen N, Baigrie RJ, Heryet A, Lane DP, et al. p53 expression in colorectal adenomas. Am 7 Pathol 1993;142:87-93.

21 Van den Berg FM, Tigges AJ, Schipper MEI, Den HartogJager FCA, Kroses WGM, Walboomers JMM. Expression of the nuclear oncogene p53 in colon tumours. $\mathcal{F}$ Pathol 1989;157:193-9.

22 Gusterson BA, Anbazhagam R, Warren W, Midgely C, Lane DP, O'Hare M, et al. Expression of p53 in premalignant and malignant squamous epithelium. Oncogene 1991;6: 1785-9.

23 Davidoff AM, Kerns BJ, Iglehart JD, Marks JR. Maintenance of $\mathrm{p} 53$ alterations throughout breast cancer progression. Cancer Res 1991;51:2605-10.

24 Casson AG, Mukhopadhyay T, Cleary KR, Ro JY, Levin B, Roth JA. p 53 gene mutations in Barrett's epithelium and esophageal cancer. Cancer Res 1991;51:4495-9.

25 Spechler SJ, Goyal RK. Barrett's esophagus. N Engl f Med 1986;315:362-71.

26 Ramel S, Reid BJ, Sanchez CA, Blount PL, Levine DS, Neshat $\mathrm{K}$, et al. Evaluation of p53 protein expression in Barrett's esophagus by two-parameter flow cytometry. Gastroenterology 1992;102:1220-8.

27 Younes M, Lebowitz RM, Lechago LV, Lechago J. p53 protein accumulation in Barrett's metaplasia, dysplasia and carcinoma: a follow-up study. Gastroenterology 1993; 105: $1637-42$. 